\title{
Reconsidering the Traveling Theater of Today's Japan: An Interdisciplinary Approach to a Stigmatized Form of Japanese Theatre
}

\author{
By Yukihide Endo*
}

\begin{abstract}
Theater research today tends to give highest priority to scholarly materials based on academic scholarship that typically excludes that which academia sees as marginalized because of its origin or current status. According to this essentialist mindset, Japanese traditional theater is epitomized by nô, kabuki, and bunraku. Yet Japan has another important form of traditional theater on the margins of its society. This theater is called taishu-engeki and it caters exclusively to working-class audiences. Although resembling Kabuki, it nevertheless remains ignored by mass media and scholars alike. The troupes of taishü-engeki travel nationwide on a monthly basis. This lifestyle accounts for their persistent stigmatization and ostracism. This paper argues that the continuing presence of taish $\bar{u}$-engeki implies that the traditional Japanese folk mentality, at a subconscious level at least, accepts this marginalized theater form historically deemed extremely vulgar. Not unlike other outcast groups, traveling entertainers' nomadic lifestyles reinforced their stigma of being awesome monsters. These nomads were the ancestors of taishü-engeki. Such awe-inspiring double stigmatization experienced by today's taishu-engeki as well as the medieval entertainers provides the basis for empowering the creation of sacred time and space while on stage.
\end{abstract}

Keywords: Invisible, Itinerant, Religious, Stigma, Taish û-Engeki

\section{Introduction: The Social Invisibility of a Theatrical Form in Japan Today}

Usually, traditional Japanese theater refers solely to kabuki, nô (and kyôgen comedy), and bunraku puppetry. They are classified as "art," and even as "high art." At the other extreme lies "low art" intended merely for fun and entertainment. This low art that caters to a general audience includes Takarazuka Revue, all-female musical theater (since 1913) and Shochiku ShinKigeki (since 1948) whose specialty is (lower-)middle-class family sitcoms. But at the lowest end of low art stands an almost invisible form of theater. There is no media coverage, or even mention of it. This theatrical form is what is known as taish $\hat{u}$-engeki, meaning "a kind of theater catering for the workingclass people." It can be described as live stage entertainment, characterized by an emphasis on male-to-female cross-dressed dancing and a period drama in the kabuki style. It presents a two-and-a-half-hour-long show twice a day throughout the year, with only two days off per month.

*Professor Emeritus, Hamamatsu University School of Medicine, Japan. 
The persistently marginalized social status of taish $\hat{u}$-engeki renders its players socially invisible. Aside from a limited number of enthusiasts, its presence is widely unknown in the general public. Despite an official resident registration at a particular place, the players travel continually across Japan month by month. Just like their centuries-old ancestors, they maintain a nomadic lifestyle.

This paper will demonstrate that taishû-engeki's invisibility does not mean its insignificance as art. By placing it in a historical context, I will examine its significant contribution to Japanese theater. This will illuminate the invisible yet tenacious appeal of stigmatized Japanese traveling theater troupes.

\section{Stigma Attached to Taish û-engeki: Historical Background}

In order to define and describe taish $\hat{u}$-engeki's distinct style of life and drama, it is necessary to examine its centuries-old historical background. Although its origins remain unknown, it is derived in part from various forms of street performance designed for entertainment and introduced by traveling performers from China around the $7^{\text {th }}$ century. This original form of outdoor entertainment was called sangaku, meaning a variety of entertainment forms. But as time went on, it was usually referred to as sarugaku (aka sarugô ) for reasons that are yet unproven. Sarugaku entertainers were singers, dancers, acrobats, puppeteers, magicians, and human-animal-insect impersonators. Genealogically speaking, this motley array of entertainers is the distant ancestor of what is now widely known as nô theater, but it is also related to today's taishû-engeki actors.

Like other forms of street entertainment, sarugaku remained vulgar and primitive, and continued to please and comfort those attending seasonal and holiday festivities, as well as banquets and other celebrations. Upon request, sarugaku entertainers also served the upper classes, court aristocrats included. By the late- $13^{\text {th }}$ century, this primitive form of performance art was gradually refined by itinerant, yet artistic-minded, groups of performers (dancers). It was finally perfected into high art by the $n \hat{o}$ actor and theorist Ze-ami (c. 1363 - c. 1443). He achieved this success under the patronage and encouragement of the late $14^{\text {th }}$-century national ruler, Ashikaga Yoshimitsu (1358 - 1408), the third shogun from the Ashikaga family, whose samurai clan ruled from the $14^{\text {th }}-16^{\text {th }}$ -centuries. Whereas a limited number of sarugaku entertainers became artistically sophisticated through Ze-ami and his peers/rivals' efforts, others continued to travel, and their performances remained coarse and unrefined. The vulgar form of sarugaku simply expected an instantaneous response such as laughter and surprise from mostly the commoners. In contrast, since Ze-ami's sought truth and beauty on a spiritual level it began to graner sponsorship from the nobility. However, both Ze-ami's sarugaku and the original vulgar sarugaku were continued to be socially discriminated against and treated as untouchable. 
But of great interest is that before Ze-ami's sarugaku created history as the foundation for $n \hat{o}$ theater, the original sarugaku had already begun to make its own history. It is noteworthy to mention that completely separate from Zeami's creative success, this traditional crass and crude sarugaku continued to thrive over time in its own way. In fact, pre- and non-Ze-ami sarugaku created a freakish, carnival-like atmosphere in Kyoto, the political and cultural hub of $11^{\text {th }}$-century Japan. Fujiwara no Akihira (c. 989 - 1066), a courtier-Confucian scholar, can be considered as an eyewitness to the extremely lively hustle and bustle of this Capitol. His book entitled Shin-sarugaku-ki (A New Story of the Comedy Show) demonstrates that the early $11^{\text {th }}$ century saw sarugaku's continued popularity among both the upper and lower classes (Fujiwara, 1983). Its depiction of sarugaku and other forms of nomadic entertainment reveals that this booming popularity helped to culturally enrich medieval Japan through these untouchable entertainers' efforts.

On the one hand, Ze-ami's refined sarugaku grew more and more successful. On the other, the vulgar form of sarugaku continuously developed its own unique style and remained popular as well. Both were still called sarugaku and considered as contemptible. Likewise, a 17th-century book suggests that sarugaku maintained an increasingly notorious profile in contemporary Japan. In fact, from sometime around the $13^{\text {th }}$ century when political centralization began to emerge in Japan, sarugaku itself was viewed as being morally despicable and socially unacceptable. In a book of Japanese grammar, Arte da Lingoa de Iapam/Nihon dai-bunten (Grammar of the Japanese Language, written in Portuguese and published in Japan from 1604 1608, the author João Rodrigues, a Portuguese Jesuit missionary, mentioned the fact that just like other forms of entertainment, sarugaku was unequivocally stigmatized. These stigmatized form of entertainers are (1) sarugaku entertainers/actors, (2) itinerant female dancer-singers, (3) itinerant female fortune-tellers, (4) - (5) two kinds of (Buddhist) bell-ringing entertainers, (6) unidentifiable itinerant entertainers, and (7) monkey-showmen (pp. 806-807). Though paradoxical it may seem, it is true that in spite of such discrimination, the sarugaku--whether refined (Ze-ami's nô) or vulgar (non-Ze-ami's nô)-continued to pique the interest of late $16^{\text {th }}$-century people and draw their attention. Sarugaku's high profile urged Father Rodrigues to note its presence in the book.

Although this nomadic entertainment had a great impact on medieval Japan, especially in its urban areas such as Kyoto, discrimination against its members grew fierce. The more that politically centralized medieval Japan evolved, the more stigmatized and discriminated all these entertainers became. It remains controversial among scholars exactly when and how the concept of social discrimination against them and other members of the abject class at the base of the social structure emerged in medieval Japan. This abject class included handicraftsmen who were superstitiously believed to be marvelously gifted, and street sweepers who were likewise believed to be able to purify the defilement of death by removing animal and human corpses strewn on streets. All of these outcasts were treated as non-humans (untouchables), and this 
custom served to reinforce discrimination against these stigmatized groups in subsequent eras.

In the 1970s, Yoshihiko Amino (2008), among other historians, began to focus his research efforts on medieval $-12^{\text {th }}$ through $16^{\text {th }}$ century - Japanese "outcasts" being denied human status. In Japanese post-WWII years, those who are powerless - typically farmers-—were often considered to be sheer victims of the hegemonic system. Amino became so skeptical about this ideologically biased argument that he began to denounce the oversimplified rule versus ruled dichotomy. This view had been widely accepted since the late 1940s by historians specializing in medieval and premodern Japan under the influence of the antimilitarist mentality in post-WWII Japan. His successive monographs and books posit that in reality, those discriminated against in medieval Japan were recognized as gifted artisans such as handicraftsmen. Thus, they were placed under the special patronage and guardianship of dominant Shinto and Buddhist institutions and, most importantly, of the emperor. He recognized positively the agency of those outcasts conventionally viewed as both morally untouchable and socially invisible who are left outside of the hegemonic system. Although it took some time for many other historians to approve his hypothesis, it is now considered mainstream in the study of Japanese medieval history.

Amino's successive research calls into question the widely accepted academic view of the majority of the Japanese medieval population as sedentary farmers. Under this view, those engaged in non-agricultural production are treated as insignificant. But he argues that both agricultural and non-agricultural production played a significant role in the medieval Japanese economy. By redressing the conventional bias against manufacturing, his provocative study of medieval society brings to the fore the importance of those engaged in a variety of professions other than farming. According to Amino, these professions included handicraftsmen, merchants, hunters, fishers, and entertainers. Many of these professionals often traveled through various regions across Japan. They demonstrated such amazing skills and talents that people viewed them as fascinating, but at the same time found them to be aweinspiring and terrifying. Notably, it was to this category that traveling entertainers such as sarugaku performers belonged.

\section{The Religious Connotation Subtly Embedded in Taish $\hat{u}$-Engeki}

Whereas kabuki and nô still maintain a religious connotation, no one would recognize the religious element in taish $\hat{u}$-engeki of today. Yet it can be argued that the religious connotation of taish $\hat{u}$-engeki remains perceivable from a historical perspective. In order to clarify this aspect, it is necessary to trace the origins of taish $\hat{u}$-engeki back to Japan in the $12^{\text {th }}$ and $13^{\text {th }}$ centuries.

According to Amino (2008), in these centuries across Japan, its distant ancestors (sarugaku entertainers/performers) and other members of outcast communities who were increasingly marginalized and discriminated against, 
strove to survive and continue by seeking protection from emperors. As stated above, emperors were believed to be closely connected to the divine powers of Buddhism and Shinto. Many groups of outcast professionals, handicraftsmen, merchants, and entertainers, to name a few, possessed formal letters that were alleged to have been authorized by highly revered temples or shrines, or by ancient emperors seen as being god-like. Although they alleged that their professions served a religious purpose, these allegations were believed to be true by the outcasts themselves and accepted as authentic by society. This alleged possession of authorized documents can be seen as a cunning strategy by the outcasts to survive and thrive in turbulent times and disadvantaged positions.

Obviously, troupes of today's taishî-engeki do not have such documents, or allege that they do. But as Amino and others (2001) state, their history and tradition strongly suggests that the legend of the divine authorization began around the $11^{\text {th }}$ century and has been passed down from generation to generation in order to justify the importance of their theatrical tradition. The present-day entertainer-actors' memory of this legend is now stored deep in their subconscious, and thus they are almost unaware of it. But just like their medieval ancestors, these performers stay on the road and continue to travel from place to place on a monthly basis. They are left feeling rootless and ungrounded. The non-sedentary lifestyle characteristic of these entertaineractors urges them to recreate their legendary authorized status on a subconscious level.

Curiously, the lifestyle of the taish $\hat{u}$-engeki actors is, as such, reflected in one of the most popular fictive characters of taishu-engeki's period plays. These are wandering lone gambler-gangsters who are traditionally depicted as typical heroes. They save lives by helping victims of brutality, robbery, rape and murder. Strong and courageous as they are, they are often portrayed as disobedient, sinful, and reckless sons. This ironic treatment of heroic characters serves to make the plot of each play more convoluted and intriguing so that the audience may feel encouraged to enjoy the play.

Such gamblers (-cum-gangsters) are evocatively illustrated in a poem collected in a book of popular songs that flourished around the $12^{\text {th }}$ century. This book, entitled Ryōjin hishō (Songs to Make the Dust Dance on the Beams), was compiled in 1179 by the Tonsured Emperor Goshirakawa.

My son must be in his twenties now -

I hear he's a wandering gambler

in a provincial gambling gang.

Well, he's mine, I can't hate him!

Gods of Sumiyoshi and Nishi no Miya,

I beg you, don't let him lose the game. (Kim, 1994, p. 150; original

Japanese in Usuda et al., 2000, p. 283)

Just as gambling is a typical form of risk-taking behavior, so too is a display of prowess in a serious, dangerous situation. The gambler-gangsters' 
apparent heroism would sometimes, though not always, turn out to be selfish cowardice.

Putting aside its negative connotations, in the ancient world gambling was universally associated with divine will. In his "American Indian Games" the American ethnographer Stewart Culin finds a religious element in games of chance. He argues that "there remain certain tribes in which games occupy their original place in the religious life of these people, or a middle stage in which they are practiced both as a rite and as an amusement" (Culin, 1903, p. 61). Inspired by Culin, Johan Huizinga argues that "[w]ith many peoples diceplaying forms part of their religious practices" (1950, p. 57). More recent scholars such as Kathryn Gabriel, Eileen M. Luna-Firebaugh, and Mary Jo Tippeconnic Fox (2003) have received much inspiration for their research on the sacred aspect of gambling from Culin. They have explored gambling in Native North American mythology, arguing that according to this mythology gambling is sacred by nature.

Japanese scholars also have examined divine association in games of chance. Amino emphatically discusses the close relationship between gambling and the quality of being divine. He points out the importance of considering carefully the combination of the gambler and the female shaman's divination in the early $14^{\text {th }}$-century poetry-contest scroll (originally entitled Tôhoku-in utaawase) "that illustrates an increasing array of occupations," including "trades and crafts found in Kyoto and its environs" (Yamamura, 1990, p. 513). Losing a gamble completely, this gambler was deprived of his clothes and ended up nearly naked. The shamaness is depicted as a decrepit old woman. He (Amino \& Yokoi, 2003) argues that this combination strongly suggests that traditionally, gambling was deemed to be closely associated with divination. Yet, according to Amino, it was many years prior that the shamaness was a confident medium who could convey the divine will so that the gambler might win at gambling. Social perceptions and treatment of specially-skilled outcasts, such as the gambler, shaman/ shamaness, handicraftsman, and entertainer/performers around the early $14^{\text {th }}$ century, had already begun to change. Undergoing this paradigm shift, both the gambler and the shamaness are now depicted as mere losers in the scroll (Amino et al., 1983, p. 112).

It should be noted that by employing historical documents, Amino suggests that from the $10^{\text {th }}$ century up until the early $14^{\text {th }}$ century, gambling was seen as a sacred ritual; that is, divination (Amino, 2005, p. 270). As for the history of gambling, both in Japan and worldwide, Kôichi Masukawa's work, Tobaku no nihonshi (History of Japanese Gambling), deserves acclaim for delving into the wide-ranging nature of gambling. As he notes in this book, gambling originally came into being as the sacred act of divination (Masukawa, 1989, pp. 36-42).

While gambling itself has a religious connotation, today's taish $\hat{u}$-engeki 's typical heroic character, the wandering lone gambler-gangster, is just a small part of this theater world and does not demonstrate any connection with the sacred. But metaphorically speaking, each taish $\hat{u}$-engeki troupe is a wandering lone gambler-gangster since there is no guarantee of success in winning; that 
is, attracting a potential audience to the theater chosen by the regional promoter of each district on a monthly basis. Taish $\hat{u}$-engeki troupes are totally free to win or lose and cannot help but give themselves up to the divine will, which is unknown to them. Indeed, they just let themselves go with the flow.

\section{Perpetual Itinerancy: Wandering Taish $\hat{u}$-Engeki Troupes}

Once again, the most salient characteristic of taish $\hat{u}$-engeki is its nomadic lifestyle which, as stated earlier, is reflected in the most popular fictional character -- the wandering lone gambler-gangsters appearing in its plays. Considering its cultural context, perhaps this itinerancy might embody the Buddhist notion of impermanence of being and the mutability of life. Those living their lives each in their own way are wayfarers traveling from place to place. They feel uncertain and unsure about finding happiness and peace. They all know that, like it or not, their usual dwelling is on the road.

This way of life was portrayed twice by the Japanese film director Yasujirô Ozu (1903 - 1963). These films are entitled A Story of Floating Weeds (black-andwhite and silent, 1934) and Floating Weeds (color and sound, 1959). Both are set around the 1930s and symbolically depict traveling players as "floating weeds" at the center of the film. The storylines of both films are similar in that a remote seaside village is visited by a traveling troupe. This troupe is led by a middle-aged man whose current mistress is a member of the troupe. For such an isolated community in those days, traveling players were strangers who could either provide great enjoyment or cause serious trouble. Yet, having spent many a dull and boring day, one after another, villagers become excited, half thrilled and half horrified to see the players coming.

These films show that the first victim is a middle-aged woman and her teenage son. This woman is a long-ago lover of the troupe leader, and the boy is their son. A decade or so earlier, when the leader and his troupe were in the village, he had slept with the woman but forsook her before she gave birth to the boy. Feeling guilty, he would occasionally visit them and give her money in lieu of ongoing financial support when his troupe was nearby. This time, he calls on them as usual. Ashamed of having abandoned them, he keeps his identity a secret from the boy by posing as the mother's friend. Yet this seemingly happy reunion is followed by a bitter separation because of his current mistress's violent, jealous rage. The enraged woman manipulates a novice actress into deceptively seducing the boy. She also tells the boy that the leader is his father and leaves him bitterly confused. Misfortunes never come alone. The troupe is disbanded, for one of its members has run away with all the money left in the troupe's safe. Later the leader reconciles with his mistress and both leave the village, without hope, to begin anew and drift like floating weeds. The mother and son are left heartbroken. Although they are sedentary, they too feel insecure and rootless. In the mother and son's view, the wanderer-stranger--the troupe leader--turns out to be more malevolent than benevolent. 
It was Shinobu Orikuchi (1887 - 1953), a Japanese poet-ethnologist, that brought to the fore the dual nature of the stranger in the premodern Japanese rural community. Traditionally, the Japanese believe that those who come from the outside world may bring blessings, but at the same time curses. Orikuchi theorized the seasonal visitation of the stranger, whom he termed "marebito." It refers to a visitor who appears only on special festive occasions for farmers (Orikuchi, 1975, pp. 137-138). According to Orikuchi, the marebito played a significant role in premodern Japan. In both of Ozu's films, the arrival of the traveling entertainers who are potential "marebito" figures, brings not only (fleeting) joy but also (lasting) misery.

The traveling players in both films reflect the essential nature of today's taish $\hat{u}$-engeki. The taish $\hat{u}$-engeki troupes are controlled by the nationwide commercial network of entertainment promoters. Nevertheless, their subconscious knows that just like their ancestors who used to be floating in real life, they remain wayfarers who wander from place to place. Indeed, young traveling actors' twitter topics often include their monthly travel. Although they take this itinerancy for granted, they cannot help but acutely aware of their lives are similar to floating weeds. Does this merely reflect the Buddhist view of life as a journey in the fleeting world?

\section{The Implications of the Nomadic Lifestyle of Taish $\hat{u}-$ Engeki}

In both films examined above, the traveling taish $\hat{u}$-engeki players are floating weeds which are constantly unstable, vulnerable to transience, and thus finally destined to evanescence. In appearance, this use of an aquatic metaphor, "floating," reinforces the negative view of life and existence. This metaphor also suggests that there is hope for the future. Thomas A. Tweed, a scholar of religious studies including Buddhism in the US, points out the significance of aquatic metaphors in religious activities. He argues:

Relying on the journey metaphor but figuring it as aquatic passage rather than terrestrial travel, religions in India have emphasized the importance of tìrthas, a term that originally referred to a ford, or a place to cross a river. ... In Buddhism, the Buddha's dharma, or teaching, is the vehicle that carries the follower across, and even the body can function as a means of transport ...

(Tweed, 2006, pp. 155-156).

To illustrate a point, he quotes a couple of lines from the $8^{\text {th }}$-cnetury Indian Buddhist monk and scholar Shantideva's poem entitled Bodhisattvācharyavatāra, which means "bodhisattva [enlightened being] path" (Tweed, 2006, p. 156). Shantideva metaphorically depicts the "body" as a "boat" in the following three verses: 
[Chapter 5 - Guarding introspection, Verse 70]

I should conceive of my body as a boat,

A mere support for coming and going.

And in order to benefit all others

Transform it into a wish-fulfilling body.

[Chapter 7 - The perfection of zeal, Verse 14]

Relying upon the boat of a human (body),

Free yourself from the great river of pain!

As it is hard to find this boat again,

This is no time for sleep, you fool.

[Chapter 3 - Adopting the spirit of awakening, Verse 18]

May I be protector for those without one,

A guide for all travelers on the way;

May I be a bridge, a boat and a ship

For all who wish to cross (the water)

(Shantideva, 1999).

This aquatic trope of the body as a boat helps to illumine the nature of the

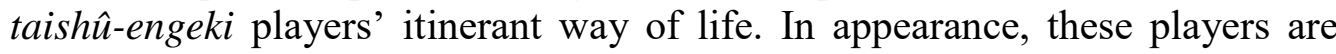
directionless wanderers, aimlessly afloat in a sea of indecision and forgetfulness. Yet in reality, although not necessarily intended, they strive to develop their sense of direction and purpose while continuing their tours. Thus, they are a group of determined travelers. As suggested in verse 18 of chapter 3 , - "all who wish to cross (the water)" - the travelers riding in the boat have their own goals and values. Having perceived their determination, the poet offers himself as their guide, assisting them in purposefully going across the water.

As argued earlier, because of their special acting and performance skills, medieval traveling entertainers received exclusively arranged protection from preeminent Shinto shrines, Buddhist temples, and godlike emperors. To highlight this, Amino repeatedly discusses the frequently overlooked importance of all those stigmatized who live in the peripheral regions adjacent to the borders between society and nature, and between life and death (2007, pp. 408-412). These outcasts include handicraftsmen and entertainers. Their professions were seen as an awesome combination of magic and technology. Indeed, inspired by their gifted skills, medieval Japan viewed them with mixed feelings of respect, dread, and wonder

Incredibly, even in the $21^{\text {st }}$ century, the socially invisible and thus stigmatized taish $\hat{u}$-engeki players have subconsciously inherited this special patronage of their ancestors. Late modern Japan's collective memory of the players' traditional stigma is also stored in the taishû-engeki's subconscious. This collective subconscious knows that these taishu-engeki players are sacred as well as profane. Similarly, those engaged in taish $\hat{u}$-engeki understand subconsciously that they are stigmatized, but at the same time deemed 
awesome, because of their excellence in dancing and acting. Figuratively speaking, they are sacred outcasts traveling across Japan to visit sacred sites called theaters. Each theater is a meeting place of the provider and recipient of

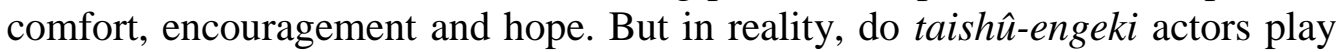
the role of the giver, while the audience acts as the recipient? No one knows. It could be vice versa, for these actors themselves seek escape from their innate contradiction. Potentially, as argued above, they are dually characterized as both a comfort for and a threat to the recipient community (i.e. the audience). The audience may help to make the pain of their self-contradiction less severe by celebrating their dancing and acting, in which the audience themselves finds comfort and encouragement.

\section{Conclusion: Stigma and Artistic Mastery}

In modern Japan, there is refined mainstream traditional theater - kabuki, $n \hat{o}$ (and kyôgen), and bunraku - on the one hand, and contemporary marginal taish $\hat{u}$-engeki on the other. Both have common origins in the unsophisticated techniques and skills of $7^{\text {th }}$ - and $8^{\text {th }}$-century traveling entertainers. Despite the comparability between the two, each has been developing its own style over the past few centuries. While endeavoring to refine and perfect their respective styles, the first group ( $k a b u k i, n \hat{o}$, and bunraku) outgrew their former selves. In other words, they were able to cast off the bitter and painful stigma of their ancestors, which signified a historically defiled status because they, as acclaimed artists, felt ashamed of such a humiliating stigma. Considering their established mainstream status and well-sustained financial capability, they have succeeded in adapting and evolving to fit in with modern Japan today. In like manner, taish û-engeki players have already assimilated themselves into post-WWII democratic Japan. Nonetheless, so far as this theater is concerned, the social status of taishû-engeki remains stigmatized at least on a subconscious level. Yet, paradoxically, this stigmatized social status helps

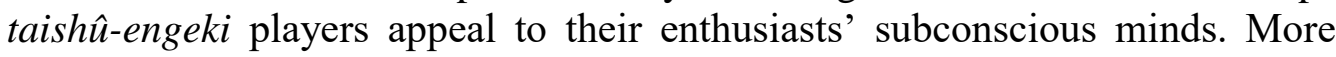
important, they thereby awaken the audience's dormant desire to imagine and experience universal - though often culturally conditioned-human emotions, such as love, anger, fear, grief, despair, and hope.

\section{References}

Amino, Y., 2005. Chûsei no hinin to yûjo (Medieval Outcasts and Prositutes). Tokyo: Kôdansha.

Amino, Y., 2007. Amino Yoshihiko chosakushû (The Collected Works of Amino Yoshihiko), vol. 12. Tokyo: Iwanami Shoten.

Amino, Y., 2008. Amino Yoshihiko chosakushû, vol. 7. Tokyo: Iwanami Shoten.

Amino, Y., et al., 2001. Nihon-rekishi no naka no hi-sabetsumin (Those Discriminated Against in the History of Japan). Tokyo: Shin-jinbutsuóraisha. 
Amino, Y., Kasamatsu, H., Ishii, S., \& Katsumata, S., 1983. Chûsei no tsumi to batsu (Crime and Punishment in Medieval Japan). Tokyo: Tokyo Daigaku Shuppankai.

Amino, Y., \& Yokoi, K., 2003. Toshi to shokunô-min no katsudô (Handicraftsmen Working in Urban Areas). Tokyo: Chûôkôronsha.

Culin, S., 1903. American Indian Games. In: American Anthropologist, New Series 5(1), pp.58-64. Also available from: http://onlinelibrary.wiley.com/doi/10.1111/ aman.1903.5.issue-1/issuetoc. [Accessed: 18 Nov. 2014].

Fujiwara, no A., 1983. Shin-Sarugakuki. Annotated by: H. Kawaguchi. Tokyo: Heibonsha.

Gabriel, K., 1996. Gambler Way: Indian Gaming in Mythology, History, and Archaeology in North America. Boulder, CO: Johnson Books.

Huizinga, J., 1950. Homo Ludens: A Study of the Play-Element in Culture. Boston, MA: Beacon Press.

Kim, Y., 1994. Songs to Make the Dust Dance on the Beams: The Ryōjin hishō of Twelfth -Century Japan. Translated. Berkeley, CA: University of California Press.

Luna-Firebaugh, E.M., \& Tippeconnic-Fox, M.J., 2003. Playing the Gods. Gambling and spirituality: A New Anthropological Perspective. In: G. Reith, ed. Gambling: Who Wins? Who Loses. Amherst, NY: Prometheus Books, pp. 334-347.

Masukawa, K., 1989. Tobaku no nihonshi (The History of Japan with Special Emphasis on Gambling). Tokyo: Heibonsha.

Orikuchi, S 1975. Kokubungaku no Hassei (The Origins of Japanese Literature, the $3^{\text {rd }}$ ed.). In: Orikuchi Shinobu-shû, Kindai-Nihon Shisô Taikei (The Collected Works of Orikuchi Shinobu: Compendium of Japanese Thought), vol. 22. Tokyo: Chikuma Shobô.

Rodrigues, J., 1604-1608 (reprinted 1955). Arte da Lingoa de Iapam/Nihon daibunten. Translated by T. Doi. Tokyo: Sanseido.

Usuda, J., et al., 2000. Ryôjin Hishô (translated into modern Japanese). In: ShimpenNihon koten bungaku zenshû (A New Edition of The Complete Works of Classical Japanese Literature). Tokyo: Shōgakkan.

Shantideva, 1999. Guide to Bodhisattva's Way of Life. Translated by S. Bachelor. Available from: http://www.abuddhistlibrary.com/Buddhism/A\%20-\%20Tibetan $\% 20 \mathrm{Buddhism} /$ Authors/Shantideva/A\%20Guide\%20to\%20the\%20Bodhisattva's \%20Way\%20of\%20Life\%20-\%20\%20Stephen\%20Bachelor\%20tra/A\%20Guide \%20to\%20the\%20Bodhisattva's\%20Way\%20of\%20Life.pdf. [Accessed: 5 Nov. 2014].

Story of Floating Weeds, A. 1934. Available from: https://www.youtube.com/watch?v =AvCiF4aYeP8 [Accessed: 2 Nov. 2014].

Tweed, T.A., 2006. Crossing and Dwelling: A Theory of Religion. Cambridge, MA: Harvard University Press.

Wallace, V.A., \& Wallace, B.A., 1997. A Guide to the bodhisattva Way of Life. Translated. Ithaca, NY: Snow Lion Publications. Available from: http://hoavouu. com/images/file/AkMNdk9R0QgQAAoD/shantideva-bodhicaryavatara-wallace. pdf. [Accessed: 25 Oct. 2014].

Yamamura, K., ed., 1990. The Cambridge History of Japan, vol. 3. Cambridge, MA: Cambridge University Press. 
